\title{
Is There any Difference in Waste Consciousness between National Eco- Schools and Others?
}

\section{Putu Nanci Riastini}

Science Education Department, Yogyakarta State University, Yogyakarta, Indonesia, Primary Teacher Education Department, Ganesha University of Education, Bali, Indonesia, putunanci.2017@student.uny.ac.id, putunanci.riastini@undiksha.ac.id

\section{Cening Sri Wati}

Elementary School 18 Dangin Puri, Denpasar, Bali, Indonesia, cening.sriwati@gmail.com

\author{
Anti Kolonial Prodjosantoso \\ Prof., Science Education Department, Yogyakarta State University, Yogyakarta, \\ Indonesia, prodjosantoso@uny.ac.id
}

\section{IGP Suryadarma}

Prof., Science Education Department, Yogyakarta State University, Yogyakarta, Indonesia, suryadarma@uny.ac.id
This study was done to explore elementary school children's waste consciousness at NES and NonNES. The pupil's consciousness was viewed from three aspects: knowledge, attitude, and action in relation to waste and its management. The study involved 647 elementary school pupils in Denpasar city, Bali, Indonesia. The data were collected using questionnaire, interview, and observation. The question coverage covers 1) the types of solid waste and the colors of the garbage bins for them, 2) waste management actions taken at school, 3) waste management difficulties faced at school, 4) pupils' attitudes when seeing an inappropriate waste disposal behavior, and 5) actions taken to reuse waste at school. The data were analyzed through qualitative and percentage analysis. The result showed that pupils' consciousness of the NES and those of the others do not differ much. Hence, the winning of the National Eco-School reputation does not guarantee the possession of a higher level of waste consciousness of the pupils than that of those who come from other schools.

Keywords: waste management, waste consciousness, national eco-school, elementary school, pupil

Citation: Riastini, P. N., Wati, C. S., Prodjosantoso, A. K., \& Suryadarman I. (2019). Is There any Difference in Waste Consciousness between National Eco-Schools and Others? International Journal of Instruction, 12(4), 513-528. https://doi.org/10.29333/iji.2019.12433a 


\section{INTRODUCTION}

Waste has become a complex global problem (Comber \& Thieme, 2013; Oguz, Cakci, \& Kavas, 2010). Solid as well as liquid waste is dangerous for the environment and human life (Adejoke, Mji, \& Mukhola, 2014). Waste is produced at houses, schools, offices, industries, and hospitals (Kurian Joseph, Rajendiran, Senthilnathan, \& Rakesh, 2012; Wilkie, Graunke, \& Cornejo, 2015). Houses produced the most waste (Karak, Bhagat, \& Bhattacharyya, 2012; Pakpour, Zeidi, Emamjomeh, Asefzadeh, \& Pearson, 2014). The consumption patterns, inadequate facilities, and lack of interest in the environment to manage waste cause waste to pile up (Karak et al., 2012; Kolbe, 2015; Teksoz, Sahin, \& Ertepinar, 2010).

Success in waste management depends on the consciousness of every individual and the government (Ifegbesan, 2010; Paul, Arce-Jaque, Ravena, \& Villamor, 2012). An individual' waste consciousness consists of three domains: individual's attitude toward waste, his or her attitude toward waste, and actions that he or she takes to solve waste problems (Diamantopoulos, Schlegelmilch, Sinkovics, \& Bohlen, 2003; Krause, 1993; Prestin \& Pearce, 2010; Sharma \& Bansal, 2013). The appearance of the consciousness can be influenced by some factors such as age, gender, social status, place of residence, culture, educational level, existing facilities, opportunity to socialize, morality, and social responsibility and previous experience (Diamantopoulos et al., 2003; Krause, 1993; Pakpour et al., 2014; Ziadat, 2010). Waste consciousness can be developed through various ways such as integrating environment education into the curriculum, holding an outdoor instruction, giving examples of adults' behaviors, and mobile learning (Joung \& Park-Poaps, 2013; Patonah, Rahardjo, Cari, \& Sajidan, 2018; Uzunboylu, Cavus, \& Ercag, 2009). Essentially, the development of waste consciousness through school programs have to be done since early years (Ercan \& Bilen, 2014; Hanifah, Yusri, \& Che Ngah, 2016).Teacher becomes an actor at school and has an important role in developing the children's waste consciousness (Nazarenko \& Kolesnik, 2018). Lack of early childhood environment education causes a low environment literacy (Stern, Powell, \& Hill, 2013; Uzunboylu et al., 2009).

Many empirical studies have focused on environment education involving all levels of education (Ercan \& Bilen, 2014; He, Hong, Liu, \& Tiefenbacher, 2011). Some empirical studies have also concerned with more specific scopes such as activities of sorting waste at school, and preschool and elementary pupils' waste consciousness (Hanifah et al., 2016; Rada et al., 2016). Unfortunately, studies concerning such topic and focus are limited in number.

The fact that there were few empirical studies on elementary pupils' waste consciousness was also true in Indonesia, although this topic has become a hot issue in some recent years. The empirical studies were focused more on Program Sekolah Adiwiyata, or also known under the name Eco School, as the governmental effort to promote environmental literacy through education (Dendy, Bahrudin, Hidayah, \& Prihadi, 2017; Desfandi, Maryani, \& Disman, 2017; Prabawa-Sear, 2018; Syamsurijal, Mulyadi, Syahrul, Mappaloteng, \& Dirawan, 2016; Warju, Prawiro, Soenarto, \& Hartmann, 2017; Windayani, 2018). These studies showed four components in the eco- 
schools:1) school policy on environment; 2) integration of environment education into the curriculum; 3) environmental participative activities; and 4) environment- friendly facilities and infrastructures. To win a National Eco School title (henceforth called NES), a school has to obtain high scores in the four components. Some of the studies mentioned that this program is an appropriate effort to develop environmental literacy at the school component (Desfandi et al., 2017; Syamsurijal et al., 2016; Warju et al., 2017). However, uniquely, there were also studies that showed the opposite results. They found that the NES title competition has not actually become an effort to develop environmental literacy, but it has only focused on how schools win the reputation (Dendy et al., 2017; Prabawa-Sear, 2018; Windayani, 2018). Unfortunately, the results have not shown the difference in consciousness, especially in waste problems, between NES and regular school pupils. NES are schools that win National Eco School title and have good reputation for environmental literacy. While, regular schools (henceforth called NonNES) are schools that do not have National Eco School title. Do NES pupils have a better waste consciousness than their NonNES counterparts?

\section{METHOD}

This study was an explorative study with a mixed methods approach. Mixed methods combines quantitative and qualitative methods to understand an existing phenomenon in more detail from different perspectives (Hussain, 2013). The study was done at schools that have won NES reputation and NonNES schools.

There were 647 pupils involved and all of them have completed and submitted the questionnaire given to them. The respondents were public and private elementary school pupils in Denpasar, Bali, Indonesia. The respondents were selected from this region since the region is a big city in Bali. It is crowded with industries, tourists, and people from different cultural backgrounds so that waste problem is always a focus of attention there. Most of NES schools in Bali come from this region. The NES schools have helped in extending the Eco School program to many other schools in Denpasar and its surrounding area. In addition, the pupils in Denpasar city come from a variety of demographic backgrounds.

Table 1

Demografic Characteristics of Participants

\begin{tabular}{lll}
\hline Variabel & $\mathrm{n}$ & $\%$ \\
\hline NES & 333 & 51.5 \\
NonNES & 314 & 48.5 \\
Boys & 321 & 49.6 \\
Girls & 326 & 50.4 \\
8-10 Years old & 345 & 53.3 \\
11-14 Years old & 302 & 46.7 \\
From Denpasar & 549 & 84.9 \\
From Other Places & 98 & 15.1 \\
\hline
\end{tabular}

The data of pupils' waste consciousness was collected through questionnaire, interview, and observation. The questionnaire contained two types of questions: matching items and open questions. The questions were written based on pupil habits in terms of waste 
consciousness and its management, which reflects their knowledge, attitudes, and skills. Understanding types of solid waste and their corresponding garbage bin colors was the indicator of knowledge. The coverage of attitude and action questions were 1) attitude toward inappropriate waste disposal behavior, 2) actions of waste management at school and the difficulties faced when managing waste at school, and 3) actions to reuse waste at school. For the content validity, the questionnaire was reviewed by experts and elementary school teachers so that the instrument has been considered suitable for the types and age levels of the pupils. Judgement assessments were then calculated by using Gregory's formula. The results showed that the instrument has very good validity.

Pupils' answers were analyzed by using two different methods. The data obtained from the open-ended questions, interview, and observation were analyzed using qualitative method, and then were transformed into categories and description. For additional, categories of pupils' answers towards question related to attitude and waste handling were calculated to find the frequency and percentage. The percentages were presented in pie diagram. Then, the data gained from the matching items question was analyzed in the form of frequency and percentage. The frequency of pupils' answers on each choice was firstly calculated. It was continued by dividing the frequency with the total pupils in each group to get a percentage. The frequencies and percentages were then presented in table form and diagram.

\section{FINDINGS}

\section{Understanding Solid Waste Types and the Colours of Bins}

The first question was related to the knowledge aspect, namely understanding. The question was answered by matching the types of solid waste to the colour of the appropriate bins. The pupils answered the question based on their habits of throwing rubbish.

\begin{tabular}{|l|l|l|}
\hline Kolom $\mathbf{A}$ & $\begin{array}{l}\text { Daun dan bunga yang } \\
\text { berguguran } \\
\text { b. } \begin{array}{l}\text { Botol obat nyamuk } \\
\text { semprot }\end{array} \\
\text { c. Botol kaca sisa }\end{array}$ \\
\hline
\end{tabular}

Figure 1

Example of Pupil's Response the Item on Solid Waste Types (Colomn A) from Different Colour of Bins (Colomn B)

In English, Figure 1 is as follows: 


\section{Column A}

a. Leaves and flowers that have fallen down

b. Used mosquito repellent bottles

c. Used glass bottles

\section{Column B}

1. Red

2. Yellow

3. Green

The result showed that pupils' understanding of organic waste, both NES and NonNES, were not much different. Both of the groups had equally good understanding which was above $90 \%$. The percentage difference was only $1.13 \%$. The frequency and percentage of pupils' answers on each choice are shown as follows.

Table 2

The Frequency and Percentage of Pupils' Answers on Each Choice

\begin{tabular}{lllll}
\hline Choice & NES & \multicolumn{3}{l}{ NonNES } \\
\cline { 2 - 5 } & Frequency & Percentage $(\%)$ & Frequency & Percentage $(\%)$ \\
\hline a -3 & 320 & 96.10 & 305 & 97.13 \\
b - 1 & 163 & 48.95 & 228 & 72.61 \\
c - 2 & 113 & 33.93 & 99 & 31.52 \\
\hline
\end{tabular}

However, the situation did not occur for the other two types of waste. For recyclable rubbish, the percentage of pupils' understanding, both NES and NonNES, was below $35 \%$. In other word, they had poor understanding of recyclable waste. The percentage of NES pupils' understanding was slightly higher than NonNES, or $2.41 \%$. In the case of hazardous waste, the NonNES had a higher percentage of understanding than NES. The difference was $23.66 \%$.

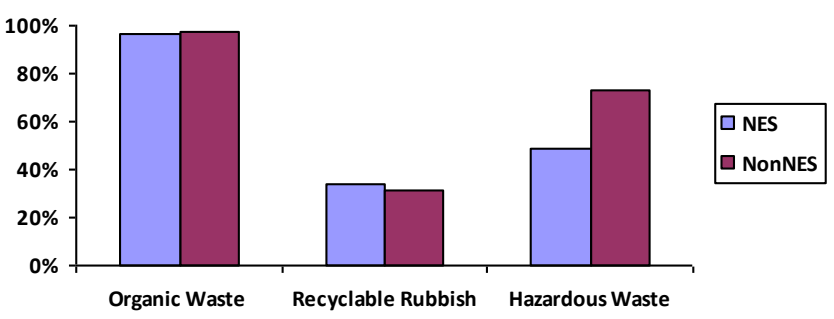

Figure 2

Comparison in Percentage of Pupils' Understanding on Solid Waste Types from Different Colours of Bins between NES pupils and their NonNES counterparts

\section{Attitude toward Inappropriate Waste Disposal Behavior}


The NES and NonNES pupils' answers toward inappropriate waste disposal behavior tend to have the same responses. The responses can be grouped into seven categories. The frequency and percentage on each category are shown as follows.

Table 3

The Frequency and Percentage of Pupils' Answers on Each Category

\begin{tabular}{lll}
\hline Categories & Frequency & Percentage (\%) \\
\hline Fed up \& Lecturing & 427 & \\
Sorry \& showing a hostile attitude & 18 & 66.00 \\
Do not care & 18 & 2.78 \\
Disappointed & 100 & 2.78 \\
Pleased \& showing concern to the waste & 12 & 15.46 \\
Picking up the waste without responding & 23 & 1.85 \\
Giving advice & 49 & 3.55 \\
\hline
\end{tabular}

The respondents' response that was shown to be dominant was lecturing as they were fed up looking at the behavior of disposing waste inappropriately. This attitude was selected by $66 \%$ of the respondents. The next dominant attitude was giving advice to the person that they saw disposing waste inappropriately. The attitude that got the smallest percentage was pleased to see other people dispose waste inappropriately to show that they did not have such kind of behavior. The pie diagram of attitude toward inappropriate waste behavior is shown as follows.

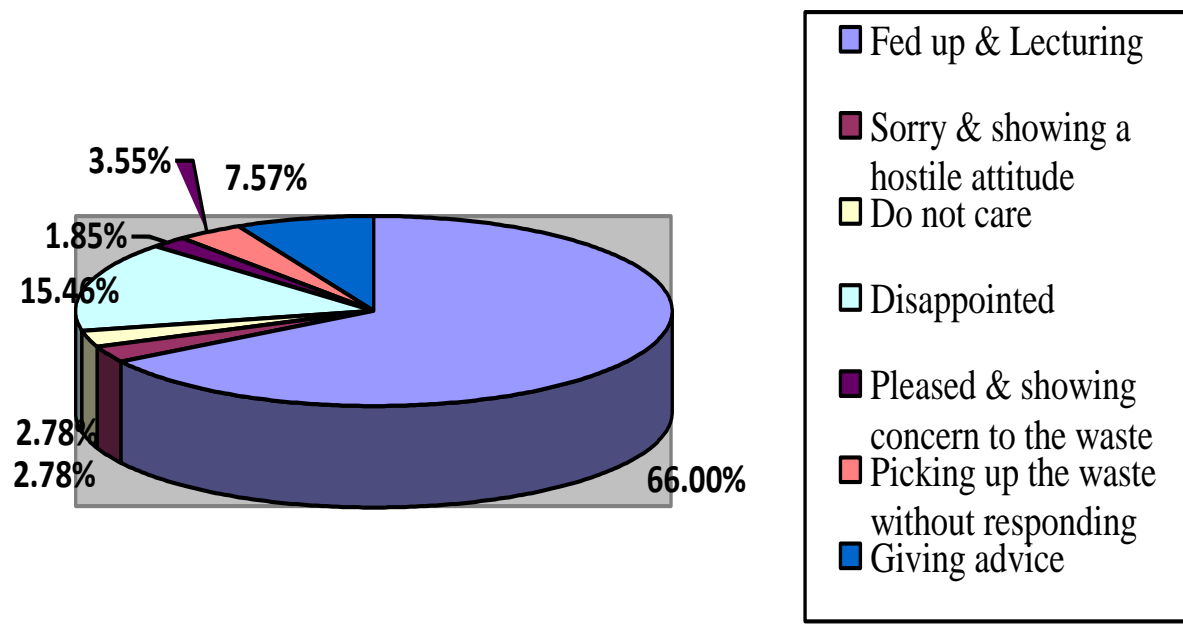

Figure 3

Categorization of Pupils' Attitude toward Waste Disposal Behavior

Actions of Waste Management at School and the Difficulties 
To address the waste problem, there were three questions made: pupils' habit in handling the waste problem at school, difficulties faced to handle waste, and actions of reusing waste. From the three types of question, data were then presented in two categories: waste handling pattern, and waste reuse actions. On the whole, both NES and NonNES had different waste management processes, depending on the pattern implemented at the school.

\section{Waste handling pattern}

In relation to the pattern of waste handling, $7.4 \%$ of the students did not give any answer. Those who did not give an answer came from NES group. Based on $92.6 \%$ of the students who answered, there were five types of waste handling done at school. These patterns are presented in the following figure.

\begin{tabular}{|l|} 
Pattern A \\
Collecting \\
Pattern B \\
Collecting $\longrightarrow$ Categorizing $\longrightarrow$ Treatment \\
Pattern C \\
Collecting $\longrightarrow$ Selecting \\
Pattern D $\longrightarrow$ Categorizing $\longrightarrow$ Disposal \\
Collecting $\longrightarrow$ Rubbish bank \\
Pattern E $\longrightarrow$ Take home \\
Collecting $\longrightarrow$ The
\end{tabular}

Figure 4

Patterns of Waste Handling at School

The frequencies and percentages on each pattern are shown as follows.

Table 4

The Frequency and Percentage of Pupils' Answers on Each Pattern

\begin{tabular}{lllll}
\hline Pattern & NES & \multicolumn{3}{l}{ NonNES } \\
\cline { 2 - 5 } & Frequency & Percentage $(\%)$ & Frequency & Percentage $(\%)$ \\
\hline A & 39 & 11.71 & 41 & 13.06 \\
B & 164 & 49.25 & 169 & 53.82 \\
C & 60 & 18.02 & 52 & 16.56 \\
D & 21 & 6.31 & 42 & 13.40 \\
E & 10 & 3 & 1 & 0.63 \\
\hline
\end{tabular}

The pattern that got the highest percentage was pattern B. Percentage of waste handling in pattern A was the second. The treatment that was usually done in pattern A was to make compost and to use waste for making handicraft in an art subject. Based on such percentages, the NES group gave a smaller contribution to each pattern compared with the NonNES, except in pattern E. The percentage for each pattern in the two types of school is shown in Figure 5. 


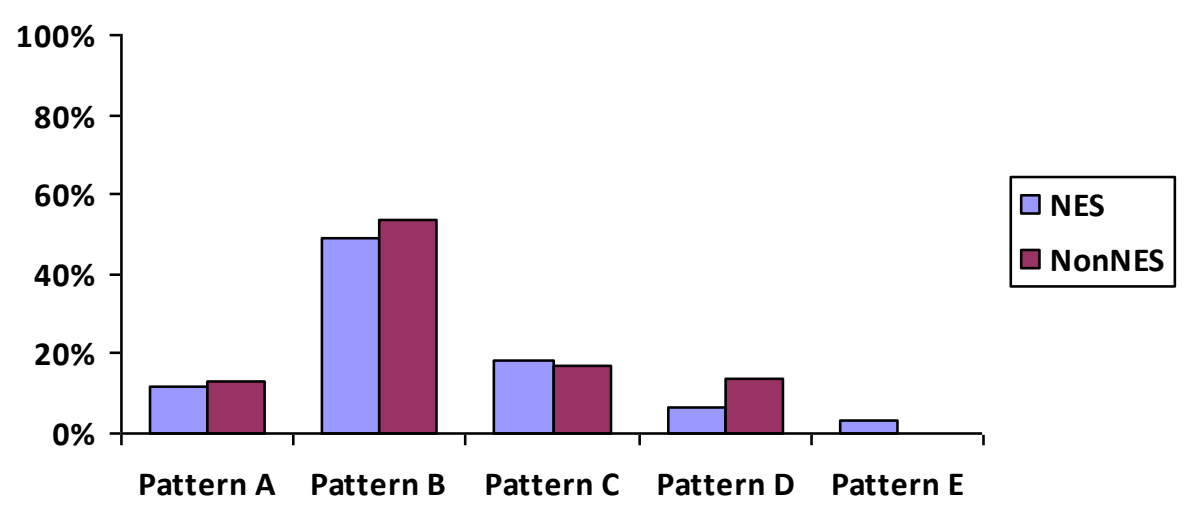

Figure 5

The Percentage of Waste Handling Patterns at NES \& NonNES Schools

The factors that caused the incomplete processes of waste handling recorded from the pupils' answers and observation were the excessive amount of waste, insufficient waste management socialization, insufficient tools, and places. Another cause recorded was the fact that the students never processed waste because they brought the waste home. None of the students mentioned the school's emphasis on recyclable rubbish and reduction activity.

Mengelola sampah adalah kegiatan rutin yang dilakukan di sekolah. Tulislah urutan langkah yang biasa kamu lakukan untuk mengelola sampah tersebut! Lihat pungut pilah dan Buang. San pahnya

Figure 6

Example of Pupil's Response for Waste Processing

Figure 6 can be translated into English is as follows. 
Question: waste management is a routine activity at school. Please write down the steps that you can take to manage waste!

Answer: see, pick, sort, and dispose

\section{The Habit of Reusing Waste}

The opposite phenomenon occurred in the reusing of plastic waste. The students had a habit of reusing waste for various art works. The types of waste that were usually selected for making handicraft were plastic, cardboards, cans, and glass bottles. The handicrafts were varied such as the use of used drinking bottles for making vases, cans for flowerpots, and cardboards for tissue boxes. And example of the work produced by the NES and NonNES group pupils by reusing plastic waste is a vase on a decorated whiteboard. The pupils' works can be seen on Figures 7.
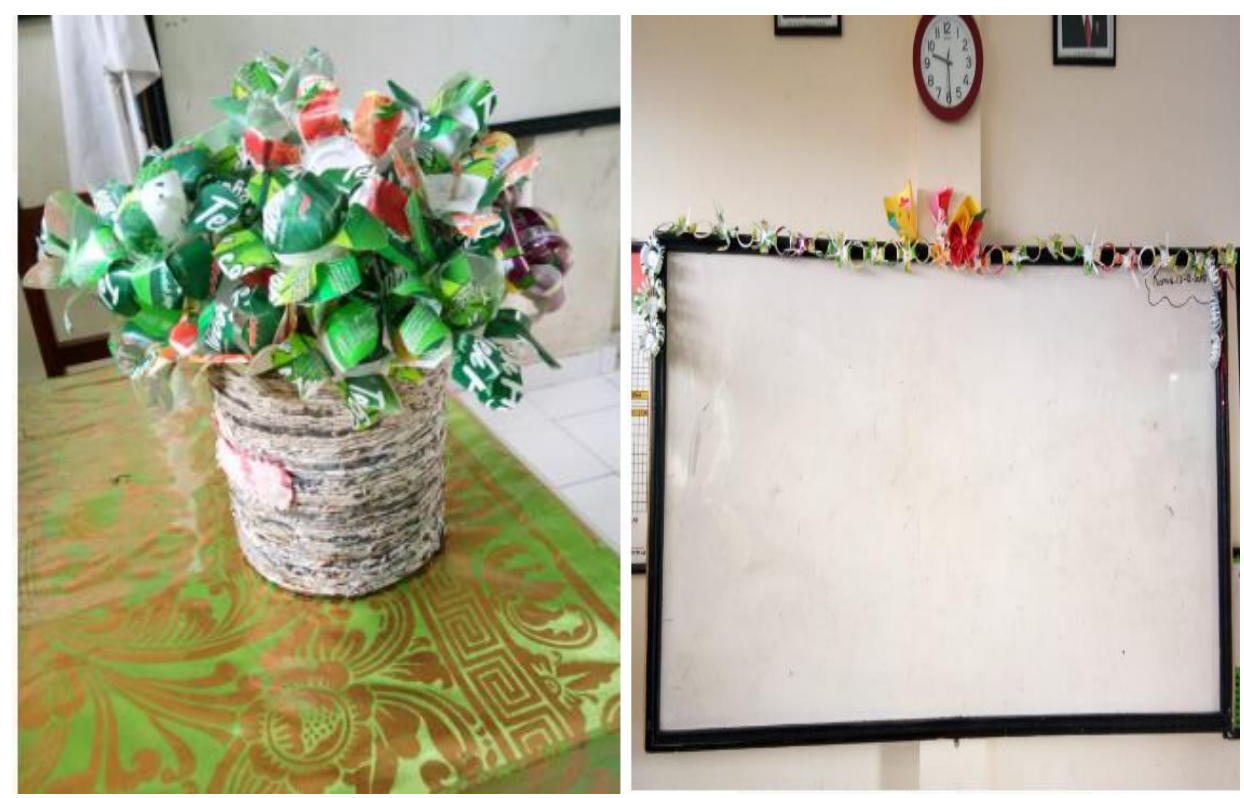

Figure 7

Vase and Decorated whiteboard Produced by Reusing Waste at School 


\section{DISCUSSION}

In general, the NES and NonNES pupils' consciousness about solid waste did not show a much difference. It means that the pupils had equivalent levels of knowledge, attitudes and actions. On the other hand, the NES group had more environmental education than the NonNES at schools. This indicates that the pupil learned by memorization in a traditional learning setting, so that it had not influenced the pupils' waste consciousness. The suitable learning climate is important for motivating waste consciousness behavior (Edumadze, Tenkorang, Armah, Luginaah, \& Edumadze, 2013; Patrick \& Ryan, 2011). This motivation becomes the drive for the pupils' instinct to apply their knowledge sustainably (Vicente-molina, Fernández-sáinz, \& Izagirre-olaizola, 2013; Wu, Lee, Chang, \& Liang, 2013).

Furthermore, competition becomes one of the means to motivate environmental consciousness, including the consciousness of waste (Gadenne, Kennedy, \& Mckeiver, 2009; Whitty \& Power, 2001). However, the competition in the bureaucratic culture leads the teaching practice once again to the concept of the traditional and noncreative teaching (Lubienski, 2003; Whitty \& Power, 2001). Competition is participated to win a reputation, public recognition, appreciation as the social strength of the school in society (Prabawa-Sear, 2018). The essence of environment education and human resources development is no longer the main focus, but the effort is focused more on winning the competition. Hence, competition does not make a much difference in the pupils' waste consciousness.

The finding also shows that the waste issue has not been deeply touched at elementary school. On the other hand, elementary school is the place to lay down the foundation for the development of environmental literacy (Kolbe, 2015). In this case, teacher is the main actor at school to control the development of students' environmental consciousness, especially the waste problem (Bergman, 2016; Teksoz et al., 2010). The setting prepared by the teacher should be holistic and makes the students to be close to the nature by integrating waste issues into the lessons (Liang, Hsu, \& Chang, 2013; Nazarenko \& Kolesnik, 2018).

Beside school, family also plays an insufficient role in developing the pupils' waste consciousness. The family plays a critical role in developing values and attitudes (Grønhøj, 2006; Sharma \& Bansal, 2013). Family is the first and essential education system and the source that supports children's education (Jeynes, 2014; Nitecki, 2015). The involvement of parents at home has a very significant contribution (Aminrad, Zarina, Sayed, Hadi, \& Sakari, 2013; Wilder, 2014). Everyday home experience that has been prepared by parents is very important to the children (Özsoy, 2012; Steinmayr, Dinger, \& Spinath, 2012). Hence, the educational process on waste at home and school has to have a strong intertwined multidimensional relation (Jeynes, 2014; Nitecki, 2015).

Another interesting phenomenon that can be observed in NES and NonNES groups was the low level of the pupils' knowledge about recyclable rubbish, but their actions of reusing waste had a good quality. It means that the treatment of the teachers in the 
teaching process separated knowledge and skill. Actually, knowledge and skill are closely intertwined, not separated (Rotherham \& Willingham, 2010). However, the process was able to motivate the pupils to produce highly aesthetical works. The contextual conditioning and problem solving produced positive experience for the pupils to imagine, create, collaborate, and communicate in handling waste (Larson \& Miller, 2011; Smith \& Hu, 2013). Creativity, collaboration, and communication are some components of the $21^{\text {st }}$ century skill (Larson \& Miller, 2011; Rotherham \& Willingham, 2010; Smith \& Hu, 2013).

\section{CONCLUSION}

Based on the aim of this study and the discussion of the result, it can be concluded that the waste consciousness of the pupils of NES and that of their counterparts (NonNES) did not have a much difference. In the aspect of knowledge, the highest percentage of the respondents' understanding was on organic waste. The NES school pupils had a higher understanding on recyclable rubbish, but they did not show better on organic and hazardous waste. When looked at from the aspect of attitude, both types of school were almost the same, so that the attitudes were classified into seven categories. The fed up and lecturing attitude had the highest percentage. From the aspect of waste handling, both types of school were grouped into five categories. The most dominant pattern was collecting rubbish -selecting. The constraints faced by the pupils when managing the waste were insufficient facilities and knowledge. In contrast, the students in both types of school were accustomed to reusing waste for making various types of good quality art works. Hence, the success in winning the National Eco-School title is not a guarantee for possessing of a higher level of waste consciousness in the pupils compared to their counterparts from other schools. As an implication, the assessment of the Program Adiwiyata in order to obtain the National Eco School title should be done with multiple methods and should involve various data sources.

\section{REFERENCES}

Adejoke, O. C., Mji, A., \& Mukhola, M. S. (2014). Students' and teachers' awareness of and attitude towards environmental pollution: A multivariate analysis using biographical variables. Journal of Human Ecology, 45(2), 167-175. https://doi.org/10.1080/09709274.2014.11906690.

Aminrad, Z., Zarina, S., Sayed, B., Hadi, A. S., \& Sakari, M. (2013). Relationship Between awareness, knowledge and attitudes towards environmental education among secondary school students in Malaysia. World Applied Sciences Journal, 22(9), 13261333. https://doi.org/10.5829/idosi.wasj.2013.22.09.275.

Bergman, B. G. (2016). Assessing impacts of locally designed environmental education projects on students' environmental attitudes, awareness, and intention to act. Environmental Education Research, 22(4), 480-503. https://doi.org/10.1080/13504622.2014.999225.

Comber, R., \& Thieme, A. (2013). Designing beyond habit: Opening space for improved recycling and food waste behaviors through processes of persuasion, social 
influence and aversive affect. Personal and Ubiquitous Computing, 17(6), 1197-1210. https://doi.org/10.1007/s00779-012-0587-1.

Dendy, M., Bahrudin, F., Hidayah, H., \& Prihadi, F. Y. (2017). The contribution of implementation adiwiyata program on environment caring character at senior high school adiwiyata in pandeglang banten. Sumatra Journal of Disaster, Geography and Geography Education, 1(2), 363-368. Retrieved from http://sjdgge.ppj.unp.ac.id

Desfandi, M., Maryani, E., \& Disman, D. (2017). Building ecoliteracy through adiwiyata program (study at adiwiyata school in Banda Aceh). Indonesian Journal of Geography, 49(1), 51. https://doi.org/10.22146/ijg.11230.

Diamantopoulos, A., Schlegelmilch, B. B., Sinkovics, R. R., \& Bohlen, G. M. (2003). Can socio-demographics still play a role in profiling green consumers? A review of the evidence and an empirical investigation. Journal of Business Research, 56(6), 465-480. https://doi.org/10.1016/S0148-2963(01)00241-7.

Edumadze, J. K. E., Tenkorang, E. Y., Armah, F. A., Luginaah, I., \& Edumadze, G. E. (2013). Electronic waste is a mess: Awareness and proenvironmental behavior among university students in Ghana. Applied Environmental Education and Communication, 12(4), 224-234. https://doi.org/10.1080/1533015X.2013.876250.

Ercan, O., \& Bilen, K. (2014). A research on electronic waste awareness and environmental attitudes of primary school students. Anthropologist, 17(1), 13-23. https://doi.org/10.1080/09720073.2014.11891410.

Gadenne, D. L., Kennedy, J., \& Mckeiver, C. (2009). Awareness and practices in SMEs an empirical study of environmental. Journal of Business Ethics, 84(1), 45-63. https://doi.org/10.1007/s10551-008-9672-9.

Grønhøj, A. (2006). Communication about consumption : a family process perspective on ' green ' consumer practices. Journal of Consumer Behaviour, 5, 491-503. https://doi.org/10.1002/cb.198.

Hanifah, M., Yusri, M. S., \& Che Ngah. (2016). 3R practices among moe preschool pupils through the. In SHS Web of Conferences (Vol. 23, pp. 1-13). https://doi.org/10.1051/ shsconf /20163420002.

He, X., Hong, T., Liu, L., \& Tiefenbacher, J. (2011). A comparative study of environmental knowledge, attitudes and behaviors among university students in China. International Research in Geographical and Environmental Education, 20(2), 91-104. https://doi.org/10.1080/10382046.2011.564783.

Hussain, I. (2013). A study of learners' reflection on andragogical skills of distance education tutors. International Journal of Instruction, 6(1), 123-138.

Ifegbesan, A. (2010). Exploring secondary school students ' understanding and practices of waste management in Ogun State. International Journal of Environmental \& Science Education, 5(2), 201-215. 
Jeynes, W. H. (2014). Parental Involvement that works... Because it's age-appropriate. Kappa Delta Pi Record, 50(2), 85-88. https://doi.org/10.1080/00228958.2014.900852.

Joung, H. M., \& Park-Poaps, H. (2013). Factors motivating and influencing clothing disposal behaviours. International Journal of Consumer Studies, 37(1), 105-111. https://doi.org/10.1111/j.1470-6431.2011.01048.x.

Karak, T., Bhagat, R. M., \& Bhattacharyya, P. (2012). Municipal solid waste generation, composition, and management: The world scenario. Critical Reviews in Environmental Science and Technology, 42(15), 1509-1630. https://doi.org/10.1080/10643389.2011.569871.

Kolbe, K. D. (2015). Knowledge, Attitudes and behaviour regarding waste management in a grammar and a comprehensive school in England - Results from a school questionnaire. Journal of Teacher Education for Sustainability, 17(1), 58-71. https://doi.org/10.1515/jtes-2015-0005.

Krause, D. (1993). Enviromental consciousness: An empirical study. Environment and Behavior, 25(1), 126-142. https://doi.org/10.1177/0013916593251007.

Kurian Joseph, Rajendiran, S., Senthilnathan, R., \& Rakesh, M. (2012). Integrated approach to solid waste management in Chennai: An Indian metro city. Journal of Material Cycles and Waste Management, 14(2), 75-84. https://doi.org/10.1007/s10163012-0046-0.

Larson, L. C., \& Miller, T. N. (2011). 21st Century skills: Prepare Students for the future. Kappa Delta Pi Record, 47(3), 121-123. https://doi.org/10.1080/00228958.2011.10516575.

Liang, C., Hsu, Y., \& Chang, C. (2013). Intrinsic motivation as a mediator on imaginative capability development. Thinking Skills and Creativity, 8, 109-119. https://doi.org/10.1016/j.tsc.2012.09.001.

Lubienski, C. (2003). Innovation in education markets: Theory and evidence on the impact of competition and choice in charter schools. American Educational Research Journal, 40(2), 395-443. https://doi.org/10.3102/00028312040002395.

McKeown-Ice, R. (2000). Environmental education in the united states: A survey of preservice teacher education programs. Journal of Environmental Education, 32(1), 4 11. https://doi.org/10.1080/00958960009598666.

Nazarenko, A. V., \& Kolesnik, A. I. (2018). Raising Environmental awareness of future teachers. International Journal of Instruction, 11(3), 63-76. https://doi.org/https://doi.org/10.12973/iji.2018.1135a.

Nitecki, E. (2015). Integrated School - family partnerships in preschool: Building Quality involvement through multidimensional relationships. School Community Journal, 25(2), 195-219.

Oguz, D., Cakci, I., \& Kavas, S. (2010). Environmental awareness of University 
Students in. African Journal of Agricultural Research, 5(19), 2629-2636.

Özsoy, S. (2012). Investigating Elementary school students' perceptions about environment through their drawings. Educational Sciences: Theory \& Practice, 12(2), $1132-1139$.

Pakpour, A. H., Zeidi, I. M., Emamjomeh, M. M., Asefzadeh, S., \& Pearson, H. (2014). Household waste behaviours among a community sample in Iran: An application of the theory of planned behaviour. Waste Management, 34(6), 980-986. https://doi.org/10.1016/j.wasman.2013.10.028.

Patonah, S., Rahardjo, S. B., Cari, \& Sajidan. (2018). The Potential of outing class activities to enhance environmental awareness for elementary school pre-services teacher. International Journal of Pedagogy and Teacher Education, 2(January), 1-6. https://doi.org/10.20961/ijpte.v\%vi\%i.19764.

Patrick, H., \& Ryan, A. M. (2011). Positive classroom motivational environments : convergence between mastery goal structure and classroom social climate. Journal of Educational Psychology, 103(2), 367-382. https://doi.org/10.1037/a0023311.

Paul, J. G., Arce-Jaque, J., Ravena, N., \& Villamor, S. P. (2012). Integration of the informal sector into municipal solid waste management in the Philippines - What does it need? Waste Management, 32(11), 2018-2028. https://doi.org/10.1016/j.wasman.2012.05.026

Prabawa-Sear, K. (2018). Winning beats learning: Environmental education in Indonesian senior high schools. Indonesia and the Malay World, O(0), 1-20. https://doi.org/10.1080/13639811.2018.1496631.

Prestin, A., \& Pearce, K. E. (2010). We care a lot: Formative research for a social marketing campaign to promote school-based recycling. Resources, Conservation and Recycling, 54(11), 1017-1026. https://doi.org/10.1016/j.resconrec.2010.02.009.

Rada, E. C., Bresciani, C., Girelli, E., Ragazzi, M., Schiavon, M., \& Torretta, V. (2016). Analysis and measures to improve waste management in schools. Sustainability (Switzerland), 8(9), 1-12. https://doi.org/10.3390/su8090840.

Rotherham, A. J., \& Willingham, D. T. (2010). "21st-Century" skills not new, but a worthy challenge. American Educator, 34(1), 17-20. https://doi.org/10.1145/1719292.1730970.

Sharma, K., \& Bansal, M. (2013). Environmental consciousness, its antecedents and behavioural outcomes. Journal of Indian Business Research, 5(3), 198-214. https://doi.org/10.1108/JIBR-10-2012-0080.

Smith, J., \& Hu, R. (2013). Rethinking teacher education: Synchronizing eastern and western views of teaching and learning to promote 21 st century skills and global perspectives. Education Research and Perspectives, 40, 86-108. Retrieved from http://www.erpjournal.net/wp-content/uploads/2013/04/ERPV40_Final_Smith-and-Ru_2013_-Rethinking-Teacher-Education.pdf. 
Steinmayr, R., Dinger, F. C., \& Spinath, B. (2012). Motivation as a mediator of social disparities in academic achievement. European Journal of Personality, 26, 335-349. https://doi.org/10.1002/per.842.

Stern, M. J., Powell, R. B., \& Hill, D. (2013). Environmental education program evaluation in the new millennium: what do we measure and what have we learned? Environmental Education Research, (September), 1-31. https://doi.org/10.1080/13504622.2013.838749.

Syamsurijal, Mulyadi, Syahrul, Mappaloteng, M., \& Dirawan, G. D. (2016). Developing Computer assisted learning media for environment education in Adiwiyata elementary school. International Journal of Applied Environmental Sciences, 11(4), 1055-1065. Retrieved from http://eprints.unm.ac.id/1659/1/Artikel International 18_47914-IJAES ok 1055-1065 email-4.pdf.

Teksoz, G., Sahin, E., \& Ertepinar, H. (2010). A new vision for chemistry education students : Environmental education. International Journal of Environmental \& Science Education, 5(2), 131-149.

Uzunboylu, H., Cavus, N., \& Ercag, E. (2009). Using mobile learning to increase environmental awareness. Computers and Education, 52(2), 381-389. https://doi.org/10.1016/j.compedu.2008.09.008.

Vicente-molina, M. A., Fernández-sáinz, A., \& Izagirre-olaizola, J. (2013). Environmental knowledge and other variables affecting pro-environmental behaviour: Comparison of university students from emerging and advanced countries. Journal of Cleaner Production, 61, 130-138. https://doi.org/10.1016/j.jclepro.2013.05.015.

Warju, Prawiro, S., Soenarto, \& Hartmann, M. D. (2017). Evaluating the Implementation of Green School (Adiwiyata) Program: Evidence from Indonesia. International Journal of Environmental \& Science Education, 12(6), 1483-1501. Retrieved from http://www.ijese.net/makale_indir/1914.

Whitty, G., \& Power, S. (2001). Devolution and choice in education. In Zukunftsfragen der bildung (pp. 99-120). Retrieved https://core.ac.uk/download/pdf/33980982.pdf\#page=100.

Wilder, S. (2014). Effects of parental involvement on academic achievement : a metasynthesis. Educational Review, 66(3), 377-397. https://doi.org/10.1080/00131911.2013.780009.

Wilkie, A. C., Graunke, R. E., \& Cornejo, C. (2015). Food waste auditing at three Florida schools. Sustainability (Switzerland), 7(2), 1370-1387. https://doi.org/10.3390/su7021370.

Windayani, Y. (2018). Study on the implementation of environmental school through adiwiyata school program on high school in the halal tourism spots of East Lombok district. Sumatra Journal of Disaster, Geography and Geography Education, 2(1), 136143. Retrieved from http://sjdgge.ppj.unp.ac.id. 
Wu, H. K., Lee, S. W. Y., Chang, H. Y., \& Liang, J. C. (2013). Current status, opportunities and challenges of augmented reality in education. Computers and Education, 62, 41-49. https://doi.org/10.1016/j.compedu.2012.10.024.

Ziadat, A. H. (2010). Major factors contributing to environmental awareness among people in a third world country/Jordan. Environment, Development and Sustainability, 12(1), 135-145. https://doi.org/10.1007/s10668-009-9185-4. 